\title{
The UK population: how does it compare?
}

Jil Matheson

National Statistician

\begin{abstract}
This is the fourth demographic report for the UK, providing an overview of the latest statistics on the population. This year's article compares the UK with other European countries and a range of nations from around the world. Statistical comparisons are made for fertility, mortality, ageing, migration and population density. The UK has an ageing population, but one that is not ageing as rapidly as some other countries such as Germany, Italy and Japan. Although life expectation in the UK is improving in line with most western European countries, relatively high levels of fertility ensure that the proportion of the population that is young remains high. Around one in ten residents of the UK are foreign born, a lower proportion than many developed countries. UK population density has increased steadily and is the fourth highest in the EU.
\end{abstract}




\section{Introduction}

This is the fourth National Statistician's article providing an overview of the current population of the UK. Earlier articles had special themes including fertility, ageing and migration. The theme of this year's article is the UK's demography in an international context, presenting data from a wide range of countries from around the world. Much of the data refers to the European Union nations, including the eight central-eastern European nations that joined the EU in May 2004 ${ }^{1}$. However, data are also presented for non-EU European countries such as Norway and Russia in order to provide a thorough comparison of European patterns. To provide worldwide coverage, data are included from: non-European developed nations such as Australia, Canada, the USA, Japan and New Zealand; emerging economies such as Brazil, China and India; and a range of developing nations in Africa. The analysis in each section below varies by both countries selected and years of comparison; this is determined by data availability for both the UK and other countries. The article summarises how the UK's population is similar to, and different from, other nations, both developed and developing.

\section{UK Overview}

The first section of this article considers the UK's recent population growth, projected population over the next quarter century, fertility levels, mortality rates and net migration patterns. Each demographic indicator is analysed in further detail later in the article and compared internationally.

\section{Population Growth and Projections}

In 2009 the population of the UK was 61.8 million $^{2}$. This was a 10 per cent increase from 56.4 million a quarter century ago in 1984. Projections indicate that if past demographic trends continue the population will rise to 72 million by 2034 (an increase of 16 per cent in the 25 years from $2009)^{3}$ (see Table 1).

The UK population was 61.8 million in 2009; this is a 10 per cent increase from 56.4 million 25 years ago

Between 1984 and 2009 the proportion of the population in the UK who were aged under 16 fell from 21 per cent to 19 per cent. The proportion aged 16 to 64 increased from 64 to 65 per cent, while the share of those aged 65 and over also increased from 15 per cent to 16 per cent. The number of people of current state pensionable age (SPA) now exceeds that of children under 16. Of those aged 65 and over, most striking was the doubling of the numbers, and the proportion, of very old people (aged 85 and over) from one per cent of the total population in 1984 to two per cent in 2009 (Table 1).

The proportion of people aged 85 and over rose from one per cent of the population in 1984 to two per cent in 2009. It is projected that by 2034 it could rise to around five per cent of the population 


\section{Table $1 \quad$ Estimated and projected population and percentage of} population by age group, UK, 1984, 2009 and 2034

\begin{tabular}{rrrrrrr}
\hline & \multicolumn{2}{c}{1984} & \multicolumn{2}{c}{ 2009 } & \multicolumn{2}{c}{2034} \\
\hline $\begin{array}{r}\text { Age } \\
\text { Group }\end{array}$ & $\begin{array}{r}\text { population } \\
\text { (millions) }\end{array}$ & $\begin{array}{r}\text { per } \\
\text { cent }\end{array}$ & $\begin{array}{r}\text { population } \\
\text { (millions) }\end{array}$ & $\begin{array}{r}\text { per } \\
\text { cent }\end{array}$ & $\begin{array}{r}\text { population } \\
\text { (millions) }\end{array}$ & $\begin{array}{r}\text { per } \\
\text { cent }\end{array}$ \\
\hline $0-15$ & 11.9 & 21 & 11.5 & 19 & 12.8 & 18 \\
$16-64$ & 36.1 & 64 & 40.1 & 65 & 42.5 & 59 \\
$65-84$ & 7.7 & 14 & 8.7 & 14 & 13.2 & 18 \\
$85+$ & 0.7 & 1 & 1.4 & 2 & 3.5 & 5 \\
\hline All & 56.4 & 100 & 61.8 & 100 & 72.0 & 100 \\
\hline
\end{tabular}

Source: Mid-year estimates 1984 and 2009, ONS, GROS, NISRA; 2008-based National Population Projections for 2034, ONS

\section{Figure 1 Estimated and projected age structure of the UK population; 1984, 2009 and 2034}

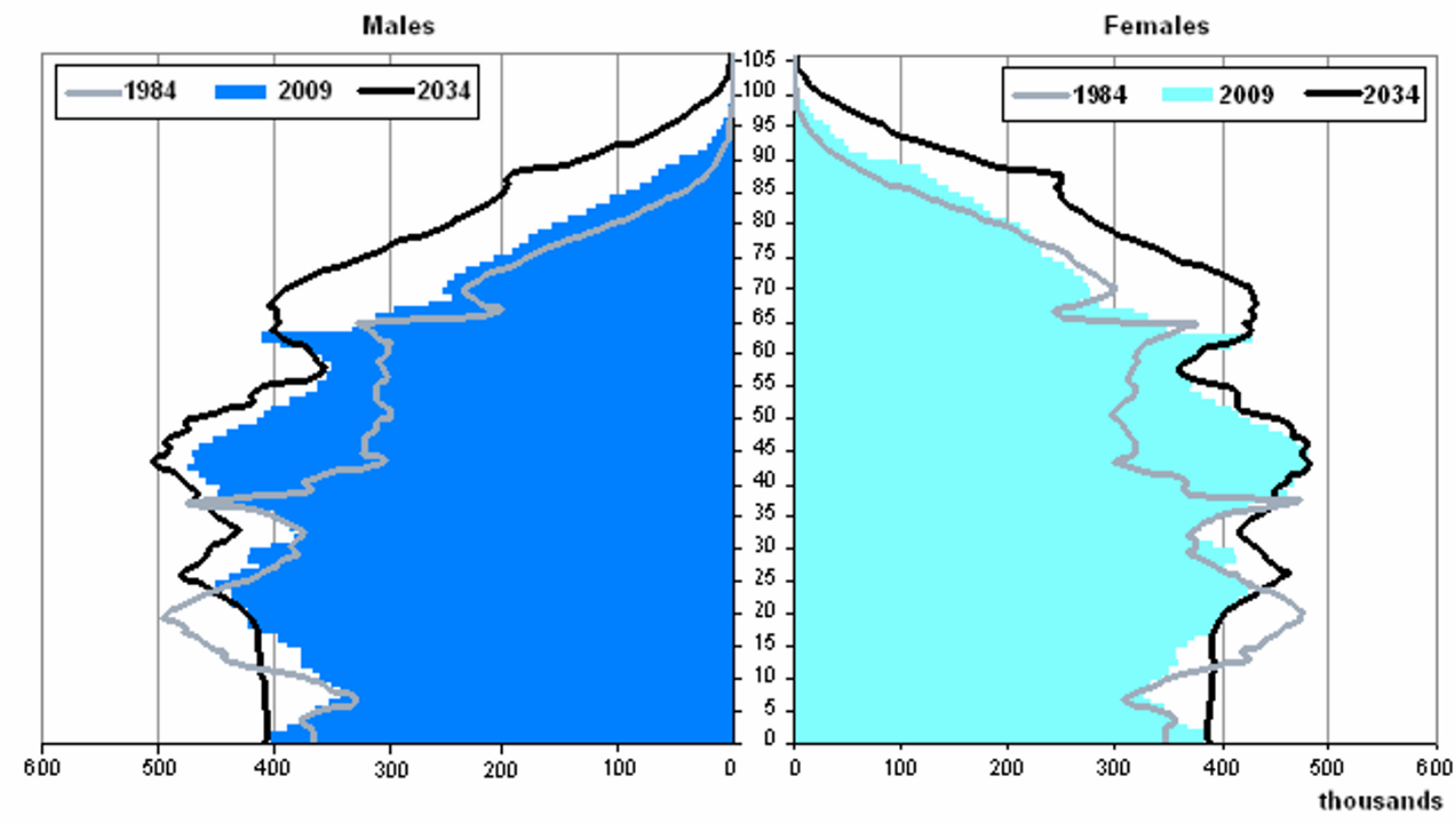

Source: Mid-year estimates 1984 and 2009, ONS, GROS, NISRA; 2008-based National Population Projections for 2034, ONS

The latest national population projections are based on the estimated population at the middle of 2008 and a set of demographic trend-based assumptions about future fertility, mortality and migration. They indicate that population ageing will continue into the future. By 2034 the proportion in the 'oldest old' population (those aged 85 and over) is projected to reach five per cent of the total population. The population aged 65 and over will account for 23 per cent of the total population in 2034, while the proportion of the population aged between 16 and 64 is expected to fall to 59 per cent. This will be due to increasing numbers of people reaching age 65 as those born in the 1960s baby boom, who are currently of working age, become older. They will be replaced by smaller 
generations in the working population. Figure 1 shows the changing age structure of the UK population over time.

The population age structure is determined by past patterns of fertility, mortality and the impact of net migration. Each of these is described briefly below.

\section{Fertility}

Fertility in the UK remained at a high level in 2009. After a fertility low point of 1.63 in 2001, shown in Table 2, the total fertility rate (TFR) ${ }^{4}$ rose year on year reaching a 35-year high of 1.96 in 2008. In 2009 it fell slightly to 1.94 , but fertility remained at levels last seen in the early 1970 s.

\section{Table 2 Total Fertility Rate and mean age of mother at birth of child in the UK, 1976-2009}

\begin{tabular}{rrr}
\hline Year & TFR & $\begin{array}{r}\text { Mean age of } \\
\text { mother at } \\
\text { birth of child }\end{array}$ \\
\hline 1976 & 1.74 & 26.7 \\
1981 & 1.82 & 27.0 \\
1986 & 1.78 & 27.4 \\
1991 & 1.82 & 27.7 \\
1996 & 1.73 & 28.2 \\
2001 & 1.63 & 28.6 \\
2008 & 1.96 & 29.3 \\
2009 & 1.94 & 29.4 \\
\hline
\end{tabular}

Source: ONS fertility rates

The higher fertility seen since 2001 is demonstrated by the bulge emerging in the base of the pyramid in Figure 1. This will have implications for planners, for example with greater demand for primary and then secondary school places over the next two decades than were previously projected based on fertility rates observed during the 1990s. The average age at which women gave birth in the UK (see also Table 2) increased from the mid-1970s onwards, reaching 29.4 years in 2009, compared to 28.2 years in 1996.

After a fertility 'low' in 2001 of 1.63, the total fertility rate rose year on year to reach a 35-year high of 1.96 in 2008; it fell slightly to 1.94 in 2009 but remains at a level last seen in the early 1970 s

\section{Mortality}

In the UK, life expectancy at birth has increased steadily over the last 20 years for both sexes and in 2007-09 was 77.7 years for males and 81.9 years for females. Figure 2 shows the increase has been larger for males ( 5.3 years) than for females (3.8 years).

Male life expectancy has increased more than female life expectancy in all four of the UK's constituent countries since 1987-89. The greatest increase for males and females has been in England (males, 5.3 years; females, 3.9 years). For males, Scotland has both the smallest life 
expectation (75.3 years) and the smallest increase of the four constituent countries (4.8 years). For females, Scotland has the lowest life expectation (80.1years), but Wales has seen the smallest increase in life expectancy (3.4 years) since 1987-89.

\section{Figure 2 Period life expectancy ${ }^{5}$ at birth for the UK and constituent countries by sex, $1987 / 89$ to $2007 / 09$}
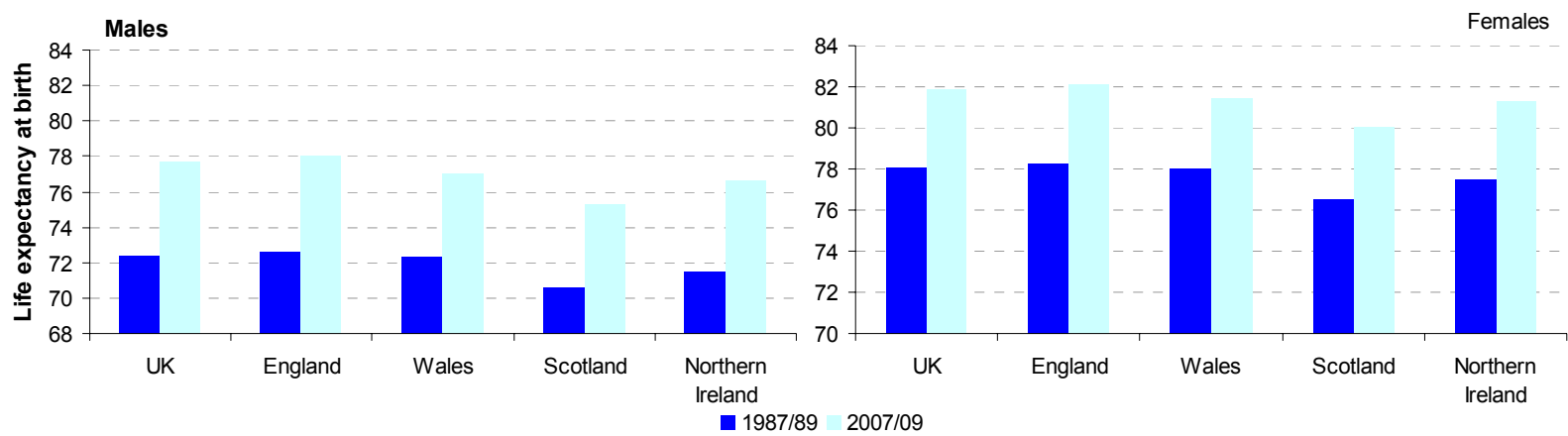

Source: ONS Interim Life Tables

The estimated number of centenarians in the UK has more than tripled in the last 25 years. In 1984 there were 3,300 centenarians living in the UK; by 2009 this had increased to 11,600. The major contributor to the rising number of centenarians is increased survival between the ages of 80 and 100 , owing to an overall improvement in medical treatment, housing, living standards and nutrition.

Life-expectancy at birth in the UK has increased steadily over the last 20 years for both sexes and in 2007-9 was about 78 years for males and about 82 years for females; the increases since 1987-89 were larger for males (5.3 years) than for females (3.9 years)

The UK has experienced a narrowing of the gender difference in healthy life expectancy (HLE) at birth (the number of years expected in good health). In 2000-2002, the gender difference was 3.1 years (males: 66.8 years, females: 69.9 years), but in 2005-2007 the difference had reduced to 2.0 years (males: 68.4 years, females: 70.4 years). HLE at birth increased at a slower rate than life expectancy for females between 2000-02 and 2005-07; life expectancy for females increased by 1.1 years whereas HLE increased by 0.5 years. For males, the rate of increase in life expectancy and HLE was the same between 2000-02 and 2005-07 at 1.6 years.

\section{Migration}

In 2008 net migration to the UK had fallen to a level comparable with the years before EU expansion in 2004, largely due to rising emigration during 2008. However, net migration rose again in 2009 as the number of immigrants remained at the levels seen since 2004, but the number of emigrants fell (Figure 3). 
These migration estimates are based on the UN definition of long-term migration and include both foreign citizens and UK nationals. Fewer British citizens chose to leave the UK in 2009 compared with 2008, and there was a rise in British citizens returning from living abroad. Foreign citizens account for 83 per cent of the total number of immigrants. There were small falls in both the number of foreigners entering the country in 2009 and the number leaving. Those arriving outnumber those departing and net migration of foreign citizens is at a similar level to 2008. Therefore the increase in total net migration observed in Figure 3 is due to fewer UK citizens leaving the UK.

\section{Figure 3 Long-Term International Migration time series, 1999 to 2009, UK}

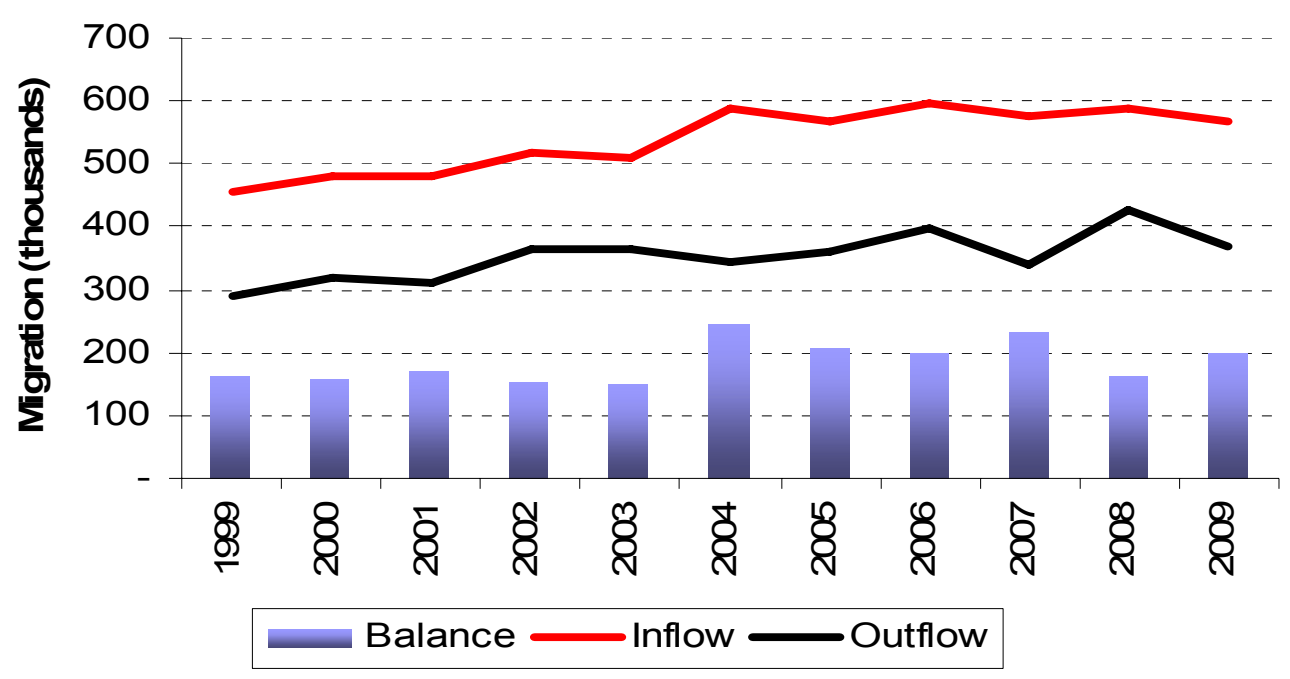

Source: ONS Long Term International Migration

In 1981, the Census showed that just over six per cent of the UK population had been born abroad (3.4 million). By 2001, this had risen to over eight per cent (4.9 million), and in 2009 people born abroad represented 11 per cent (6.9 million) of the total UK population.

In 1981 just over 6 per cent of the UK population had been born abroad; by 2009 this had risen to around 11 per cent

There has been a particular interest in eastern European migrants to the UK since the accession of eight central-eastern European countries (A8) to the EU in 2004. Between 2001 and 2009, the estimated number of people resident in the UK who were born in the A8 countries rose from 103,000 to 738,000 (Figure 4). Country of birth is not necessarily directly equivalent to citizenship as some of those born abroad may have been born with British citizenship through parentage or may have acquired it after living in the UK. 
Between 2001 and 2009 the estimated number of people resident in the UK born in the central and eastern European 'Accession' countries rose from 103,000 to 738,000; in 2009 this accounted for 11 per cent of the total foreign-born population of the UK and 1.2 per cent of the total UK population

\section{Figure 4 Foreign-born population of the UK by country of birth, 2009}

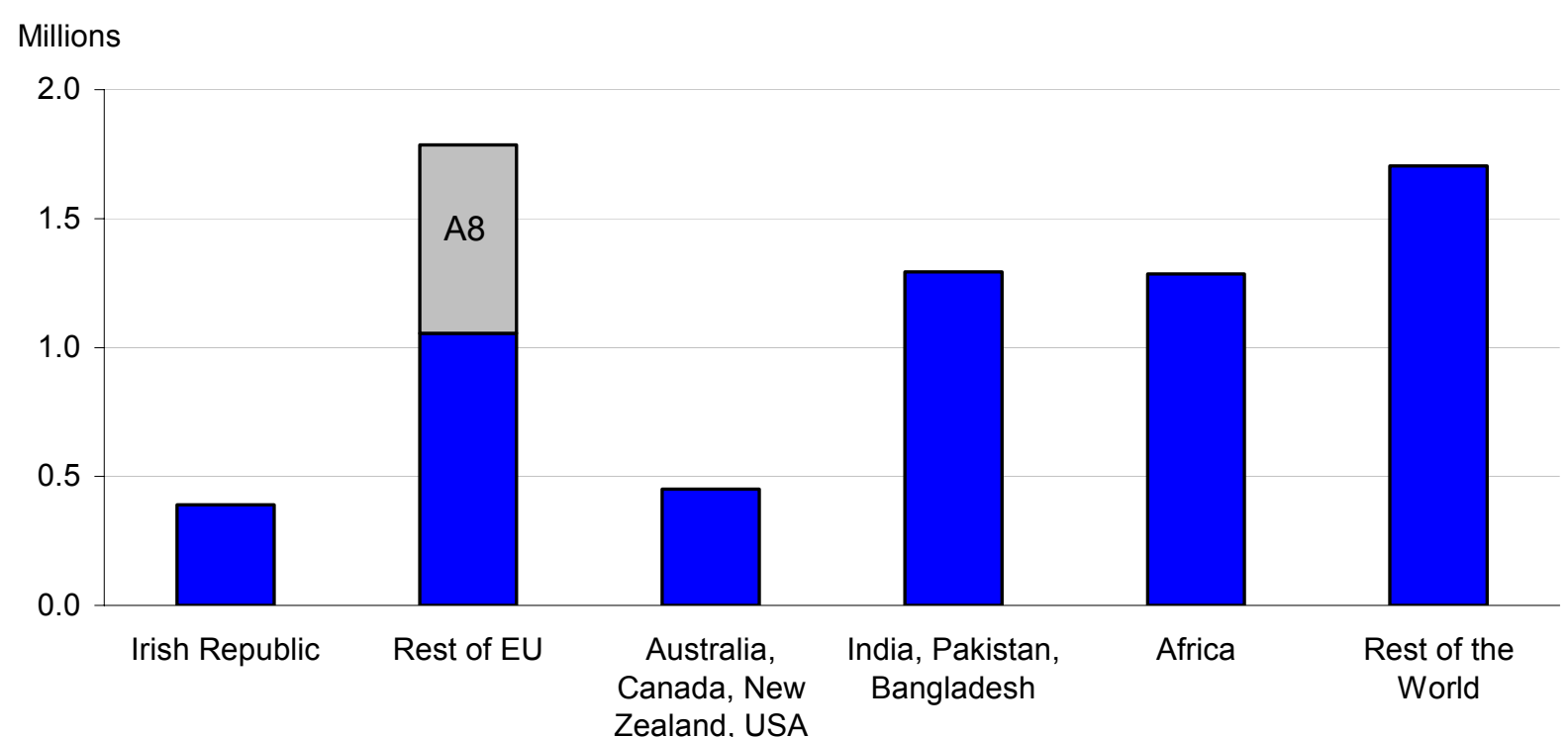

Source: ONS Annual Population Survey

\section{International Comparison}

The rest of this article places UK demography in context by making comparisons internationally. The key components considered are fertility, mortality, ageing, migration and population density. Comparisons are made with a range of other countries from within Europe and a selection of developed and developing countries from around the world.

\section{Fertility}

Figure 5 compares the UK's total fertility rate (TFR) with a broad range of countries for 2008 for which comparable data were available; these include most European countries and a range of both developed and developing nations globally. Japan and Slovakia had the lowest TFRs among these selected countries. Broadly, there was a pattern of low fertility in southern and eastern Europe and the German-speaking countries of central Europe, and higher fertility in northern Europe, Australia and New Zealand. The UK's fertility is in line with the quite high level of much of northern Europe (France, Ireland, Belgium, the Netherlands and the Scandinavian countries), with only three northern European countries (France, Ireland and Iceland) having higher TFRs than the UK. Within the global context, the UK's TFR of 1.96 is higher than that of China (1.77) and Brazil (1.88), similar to New Zealand (2.00) but lower than, for example, those of the USA (2.10), South Africa (2.54), India (2.74), Egypt (3.00), Kenya (4.92) and Nigeria (5.70). 
Fertility levels are closely associated with patterns and timings of family formation and partnership. The mean age at birth has increased for women across the EU: on average women were aged 29.3 years at birth in 2004, an increase of two years since 1985 when it was 27.3. A similar trend of increasing mean age at birth has also been seen in recent years across some developing countries, for example Kenya, China and Egypt. The average age at marriage has risen in most industrial nations in recent decades; for example, mean age at first marriage for women in the EU was 28.0 years in 2004, similar to the UK value of 28.2, and an increase of more than three years since 1990. Even countries with lower levels of development show a rise in the average age at marriage for women.

\section{Figure 5 Total Fertility Rates for selected countries, 2008 or latest data $^{6}$}

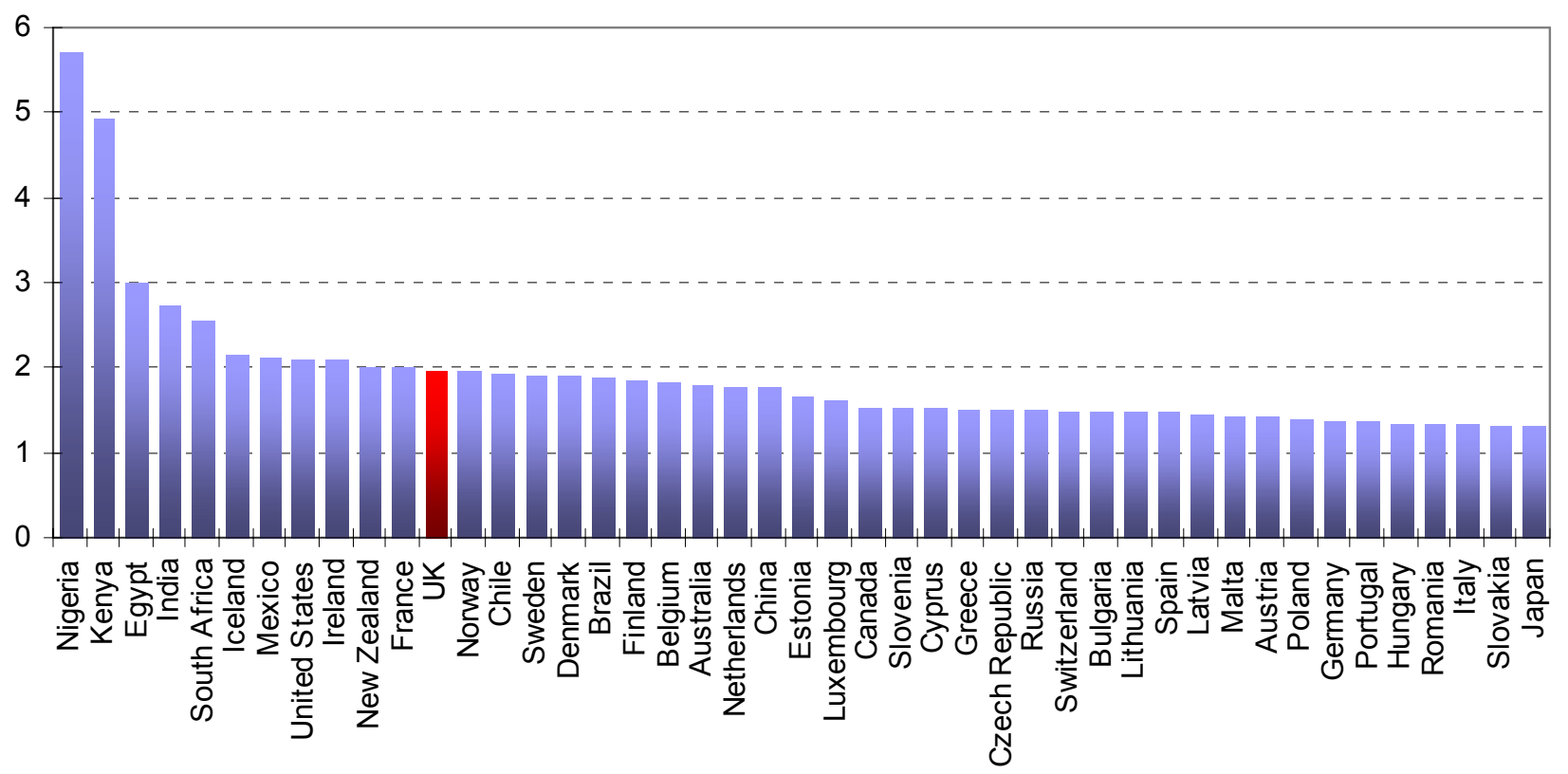

Source: ONS, Eurostat, OECD, CAMPAS and World Bank ${ }^{6}$

Figure 6 summarises the proportion of births within marriage ${ }^{7}$ in 2008 for the UK and other developed countries where data are available. It shows that the proportion of births inside marriage varies considerably from more than 90 per cent in Japan, Greece and Cyprus to less than 50 per cent in France, Bulgaria, Slovenia and some of the Scandinavian countries. The UK, along with Finland, the Netherlands, Latvia, Denmark and New Zealand, lies in an intermediate cluster of between 50 and 60 per cent of children born inside marriage.

Many of the countries where the proportion of births within marriage is high are those with the lowest fertility rates (Japan, Poland, Italy, Malta, Switzerland, Slovakia and Lithuania). In contrast, developed countries with above average fertility in 2008 are generally those with lower proportions of births within marriage (Iceland, Norway, Sweden, France and UK). This may be because in countries where childbearing outside marriage is less accepted, the shifts to later marriage and lower marriage rates have resulted in very low fertility, while those countries where childbearing is not restricted to marital unions tend to have higher fertility. There are, however, exceptions; for 
example, Estonia has a low proportion of births within marriage but also a comparatively low fertility rate.

\section{Figure $6 \quad$ Percentage of births within marriage, for selected countries, latest available data (UK 2008)}

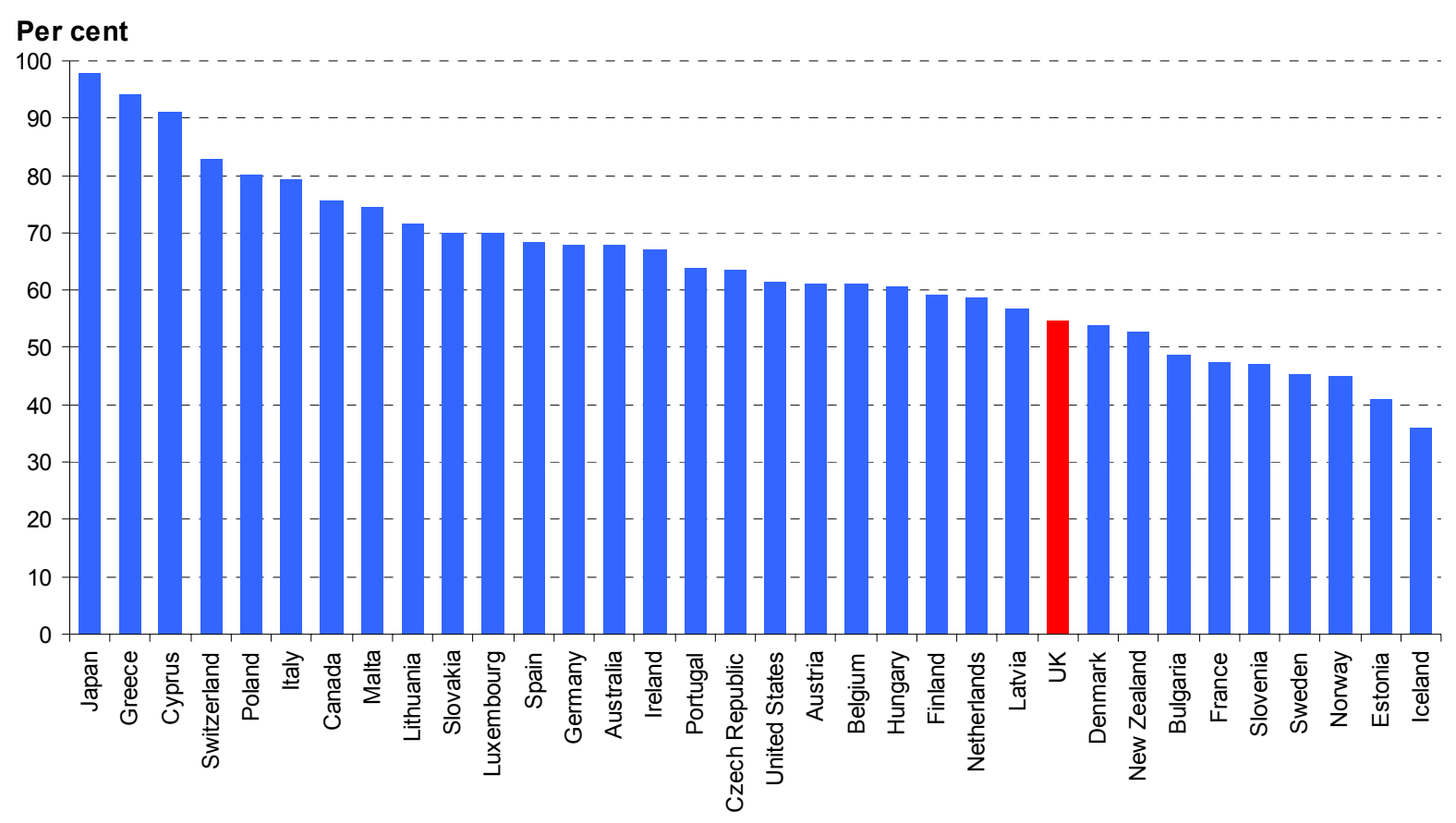

Source: ONS, Eurostat and OECD ${ }^{8}$

\section{Mortality}

Figure 7 shows life expectancy at birth for 34 countries for 2005-10. According to United Nations statistics, life expectancy at birth for males is longest in Iceland ( 80.2 years) and for females is longest in Japan (86.2 years). Out of the countries considered, the UK has the 10th highest life expectancy for males and the 14th highest for females (jointly with Slovenia). In addition to Japan and Iceland, the countries having higher life expectations than in the UK for both males and females are Italy, Australia, Finland, Canada, Norway, New Zealand and the Netherlands.

A representative selection of the 12 countries granted accession to the European Union since 2004 is included in Figure 7; these include the countries with the highest and lowest life expectancy among the Accession group. Broadly, most of the Accession countries have lower life expectancy than the 'old' EU nations. Slovenia has the highest life expectancy at birth (males: 74.6 years, females: 81.9 years); it is also the only 'new' EU country with an equal or higher female life expectancy at birth than the UK. Romania has the lowest life expectancy at birth of the Accession countries (males: 69.1 years, females: 76.2 years).

Iceland has the highest life expectancy at birth for males (80.2 years) and Japan for females (86.2 years); the equivalent UK figures are 77.7 for males and 81.9 for females 


\section{Figure $7 \quad$ Period life expectancy at birth by country and sex, 2005/10}

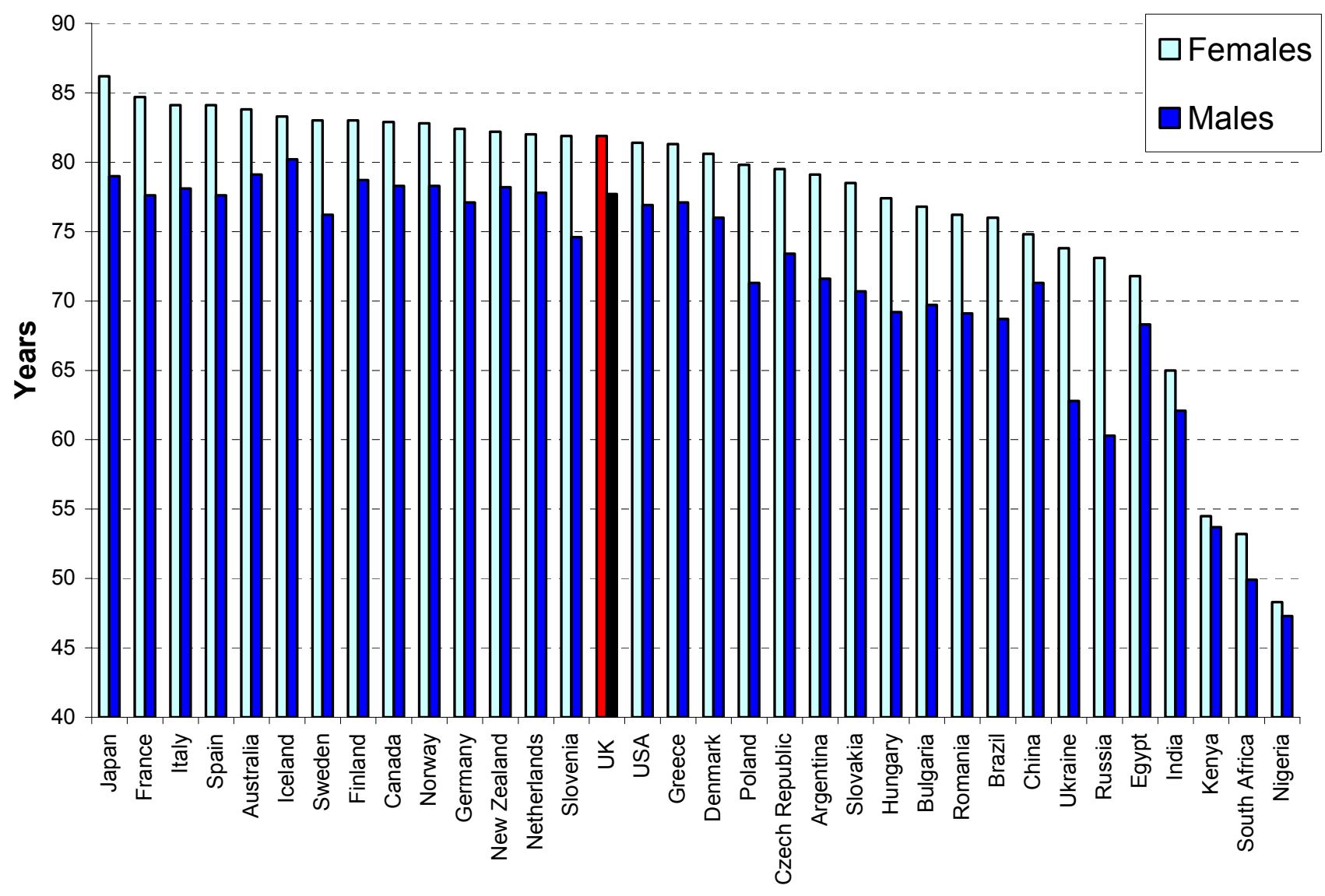

Source: ONS and UN

Figure 8 shows the change in period life expectancy at birth over the period 1985-90 to 2005-10 for the same countries as Figure 7. Among the selected countries, Egypt has experienced the greatest increase in male and female life expectancy at birth over the period: 8.1 years for males and 8.9 years for females. The other African countries included have shown smaller improvements or even falls in life expectancy over this period. South Africa has experienced the largest decrease in life expectancy of all the 34 countries, 7.2 years for males and 11.1 years for females.

Outside Africa, two countries, Russia and Ukraine, have also seen falls in life expectancy since 1985-90. Male life expectancy in Russia now stands at 60.3 years, a fall of 3.5 years, and female life expectancy is now 73.1 years, having decreased by 0.5 years. A similar change has occurred in Ukraine, where male life expectancy has fallen by 3.2 years and female life expectancy by 0.6 years over this period.

Despite considerable improvements in life expectancy in the UK, some other countries have experienced even larger improvements, most notably Egypt, Brazil, New Zealand, Australia and China. There has also been a significant improvement in the life expectancy of Indian women. The improvements in life expectancy in the UK are similar to those experienced in most northern and western European countries. 


\section{Figure $8 \quad$ Changes in life expectancy at birth between 1985/90 and 2005/10}

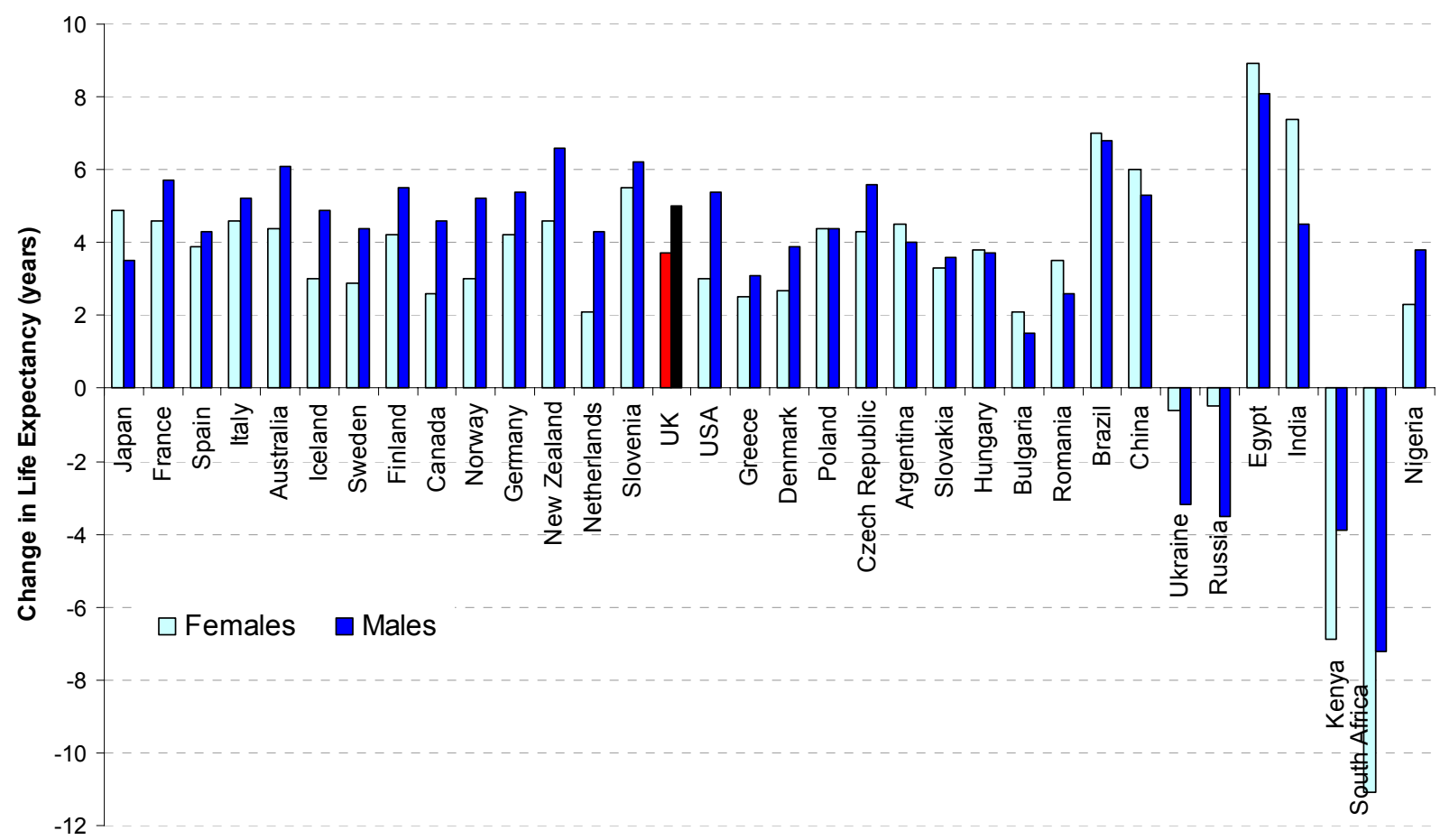

Source: ONS and UN data ${ }^{9}$

In the last 20 years the gender difference in life expectancy at birth in the UK has narrowed by 1.3 years, with women living longer than men. Most countries have seen a narrowing in this difference but there are some notable exceptions where it has widened: these include India (2.9 years difference in 2005-10 compared with 1985-90), Russia (3.0 years), Ukraine (2.6 years) and Japan (1.4 years).

\section{Ageing}

\section{Ageing between 1985 and 2009}

In this section latest available data for UK and Europe are for 2009, but for the rest of the world the latest data relates to 2008; these latest data are compared to those for 1985 as the closest available approximation to a 25-year comparison. Ageing is measured by the proportion of the population that is aged 65 and over. Countries like the UK with high life expectancy but also high fertility rates will have a high proportion of children which will help to moderate future ageing (these include Iceland, the USA and France). Countries with high life expectancy and low fertility rates will have more ageing populations (such as Japan, Italy and Germany).

In the mid 1980s, the UK was one of the more aged countries in Europe with 15 per cent of the population aged 65 or over. The country with the highest proportion of older people in western Europe at that time was Sweden with 17 per cent of the population aged 65 or above. European countries with the lowest proportions of older people were Malta, Slovakia, Poland and Romania, all with nine per cent of their populations aged 65 and over. Turkey was the least aged with only four per cent of the population in this age group. 
Over the period 1985 to 2009 , there was an increase in the proportion of older people in the populations of almost all European countries, with most of the largest increases occurring in Eastern European countries. Part of the explanation for this was the natural ageing of the population combined with a marked decline in fertility in this region. In Ireland and in Norway, where fertility rates were relatively high, the proportion of the population aged 65 and above remained constant over the period at around 11 per cent and 15 per cent respectively.

By 2009, the proportion of the population aged 65 and over in the UK had risen slightly to 16 per cent $^{10}$; however, the UK was no longer one of the most aged populations amongst European countries (see Figure 9). By 2009 the UK had a mid-ranking status compared to other European countries. One factor contributing to this fall was the relatively high fertility in the UK compared to countries in central, southern and eastern Europe for much of this period. Germany and Italy, both with consistently low fertility, had the highest proportions of their populations aged 65 and over in 2009 (both at 20 per cent) ${ }^{11}$.

Between 1985 and 2009 the UK experienced a relative fall from one of the most aged populations in Europe to mid-ranking status; the major factor responsible for this was the relatively high northern European fertility found in the UK compared to that of other parts of Europe

In 2008 Japan was the world's most aged country. There was a rapid increase in the proportion of older people in Japan between 1985 and 2008; during this period, the proportion of people aged 65 and over more than doubled from 10 per cent to 22 per cent of the population. In 2008 around 14 per cent of the populations of Canada and Australia were aged 65 and over; in New Zealand and the USA the proportion was 13 per cent. Although less aged than some European countries and the UK, these developed countries are notably more aged than those countries with more recently emerging economies such as China, Brazil and India, where the respective proportions were eight, seven and five per cent.

Africa is the least aged region of the world owing to both higher fertility and much lower life expectancy. In 2005 (the latest data available), the proportions of over 65s in Egypt and in South Africa were 5 per cent and 4 per cent respectively, and in both Kenya and Nigeria only 3 per cent of their populations were aged 65 and over.

\section{Projected ageing between 2009 and 2035}

The populations of all European countries are projected to become more aged over the next quarter century ${ }^{12}$. The UN publishes projection data for every fifth year, so 2035 is used here as the closest approximation to a 25-year comparison. In 2009, the proportion of the population aged 65 and over was under one fifth for most European countries; by 2035 the average proportion of the population aged 65 and over across the $27 \mathrm{EU}$ countries is projected to rise to a quarter.

In the UK, it is projected that the proportion of the population aged 65 and over will rise from 16 per cent in 2009 to 23 per cent in $2035^{13}$. However, the UK is not expected to age as fast as many other European countries over this period; the main reason for this is that the fertility rate in the UK 
is not projected to fall to the low levels found outside northern Europe. By 2035 the UK will rank as one of the least aged countries in the EU as shown in Figure 9.

The UK's 65 and over population is expected to rise from 16 per cent in 2009 to 23 per cent in 2035; however, by 2035 the UK will rank as one of the least aged countries in the EU

Figure 9 Percentage of actual and projected population, aged 65 and over by selected countries, 2009 and 2035

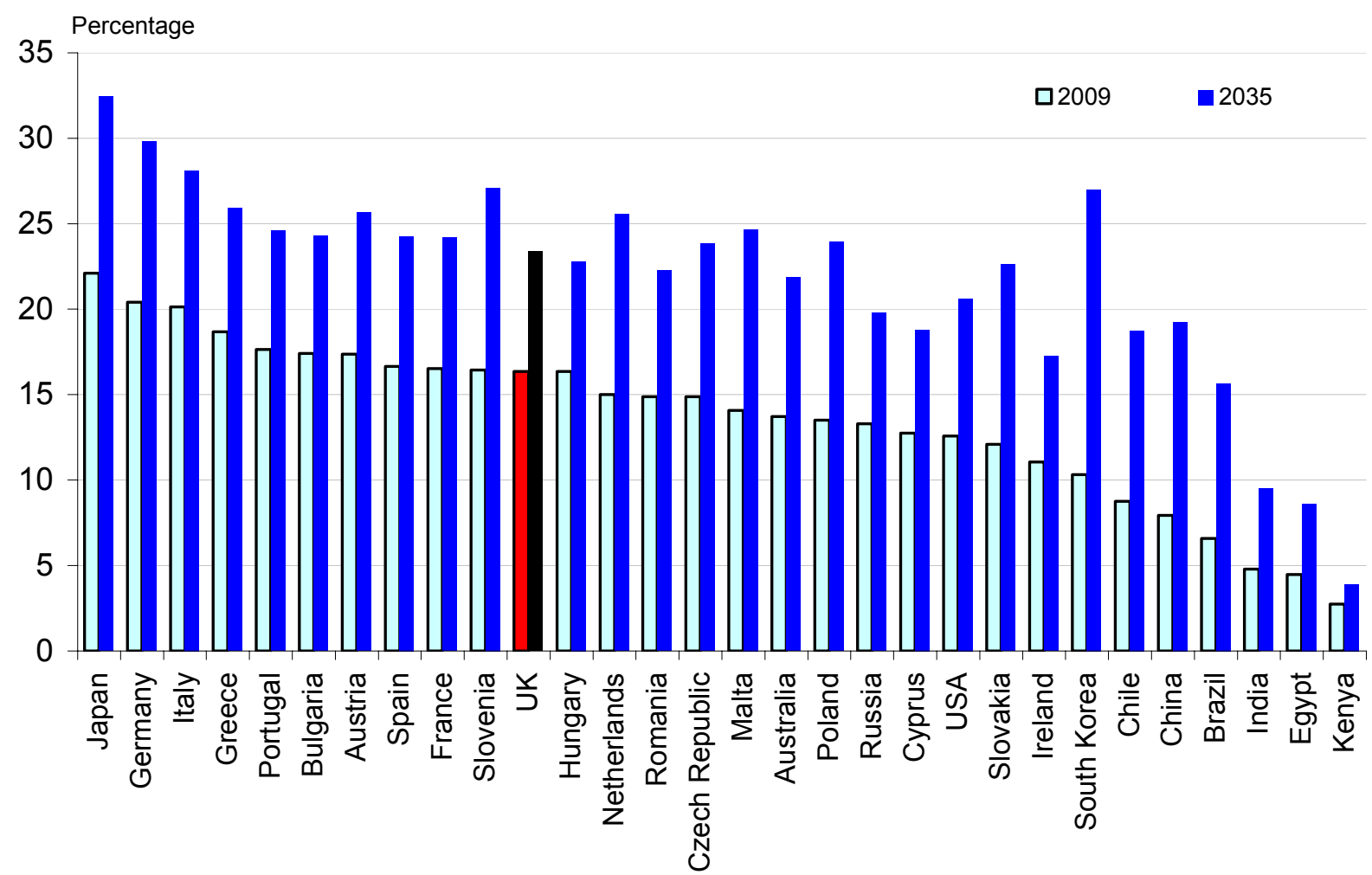

Source: ONS, Eurostat, OECD and UN ${ }^{14}$

Note: Non European countries use 2008 or 2005 data instead of 2009, all countries projections are for 2035.

European countries which were the least aged in 2009 are projected to experience some of the largest increases in proportions of the population aged 65 and over in the next quarter of a century. Rapid increases are projected for many of the 'new' EU countries, Ireland and the Netherlands. However, Italy and Germany are projected to retain their positions as the EU countries with the highest proportions of older people, with 29 per cent and 30 per cent respectively of their populations aged 65 and over.

Japan is already the world's most aged nation; moreover, by 2035 it is projected that almost a third of Japan's population will be aged 65 or over and 14 per cent will be aged 80 or above. 
Japan is the world's most aged country: in 2008, 22 per cent of the Japanese population were aged 65 or above. By 2035 one third of Japan's population will be aged 65 or over and 14 per cent will be aged 80 or over

Brazil, Chile, China, India and South Korea (countries with relatively recently emerging economies) are projected to age rapidly over the next 25 years. In 2008, these countries all had populations with relatively low proportions aged 65 and over (10 per cent or less). Projected figures indicate that the proportion of those aged 65 and over in these countries will have at least doubled by 2035.

In Africa, those countries in the north of the continent are projected to age more rapidly than subSaharan African countries. The proportion of the population aged 65 and over will almost double for Egypt by 2035, from an average of 4.5 per cent in 2005 to 9 per cent, compared to an average rise from 3 per cent to 4 per cent in sub-Saharan countries over the same period. Although the projected change in the proportion of the aged in Sub-Saharan Africa is very small, the number of older people in the region will increase by more than 2.5 times from 23.4 million in 2005 to 59.4 million in 2035.

The number of centenarians in the UK is projected to reach 97,000 by 2035 , more than an eightfold increase from the 2009 figure of 11,600. Japan is projected to have around 420,000 centenarians by 2035 and Europe in total around 529,000. By contrast, by 2035 Africa is projected to have around 10,000 .

\section{Old Age Dependency Ratios 2009 and 2035: International comparisons}

The Old Age Dependency Ratio (OADR) ${ }^{15}$ - which measures the number of people aged 65 and over for every 100 people aged 15 to 64 - is an indicator of the ratio of older people to adults of working age in a country's population. However, this is a demographic measure and not an indicator of the economic support ratio of a country (as younger people delay joining the labour market to remain in education and older people are working past retirement age). As the UK population ages, the OADR is projected to rise; from 24 in 2008 it is projected to increase steadily to 39 people aged 65 and over for every 100 people aged $15-64$ by 2035 .

Table 3 shows estimated and projected OADRs for 2008 and 2035. The UK had an OADR of 24 people aged 65 and over for every 100 people aged 15-64, very close to the average for the EU. Within the EU, Ireland had the lowest OADR (16) and Germany and Italy had the joint highest (30). Outside Europe, India had a very low OADR relative to other countries (8); in Africa the OADRs were even lower, for example, Egypt and South Africa (both 7), Nigeria (6) and Kenya (5). Japan had by far the highest OADR, reflecting its status as the world's most aged country, with 34 people aged 65 and over for every 100 aged 15-64.

The old aged dependency ratio (OADR) for the UK is currently very close to the EU average and will remain close to that average throughout the period to 2035. However, by 2035 the UK's OADR will be much lower than countries such as Germany, Italy or Japan. 


\section{Table $3 \quad$ Ranked old age dependency ratios for 49 countries, for the latest comparable year, 2008, and 2035 projections}

\begin{tabular}{|c|c|c|c|}
\hline \multicolumn{2}{|c|}{2008} & \multicolumn{2}{|c|}{2035} \\
\hline Country & OADR & Country & OADR \\
\hline Japan & 34 & Japan & 57 \\
\hline Italy & 30 & Germany & 53 \\
\hline Germany & 30 & Italy & 48 \\
\hline Greece & 28 & Finland & 46 \\
\hline Sweden & 27 & Slovenia & 45 \\
\hline Belgium & 26 & Netherlands & 45 \\
\hline Croatia & 26 & Austria & 43 \\
\hline Austria & 25 & Greece & 43 \\
\hline Estonia & 25 & Switzerland & 42 \\
\hline France & 25 & France & 42 \\
\hline Bulgaria & 25 & Denmark & 41 \\
\hline Latvia & 25 & Croatia & 41 \\
\hline Finland & 25 & Belgium & 40 \\
\hline Spain & 24 & Portugal & 40 \\
\hline Switzerland & 24 & Malta & 40 \\
\hline United Kingdom & 24 & Spain & 40 \\
\hline Denmark & 24 & Sweden & 40 \\
\hline Hungary & 24 & Bulgaria & 39 \\
\hline Portugal & 23 & Canada & 39 \\
\hline Slovenia & 23 & United Kingdom & 39 \\
\hline Lithuania & 23 & Lithuania & 39 \\
\hline Norway & 22 & Poland & 38 \\
\hline Netherlands & 22 & Czech Republic & 38 \\
\hline Romania & 21 & Norway & 38 \\
\hline Luxembourg & 21 & Latvia & 37 \\
\hline Czech Republic & 21 & Hungary & 36 \\
\hline Australia & 20 & Estonia & 36 \\
\hline Canada & 20 & Australia & 36 \\
\hline Malta & 19 & South Korea & 36 \\
\hline New Zealand & 19 & Romania & 35 \\
\hline USA & 19 & Slovakia & 35 \\
\hline Poland & 19 & Iceland & 34 \\
\hline Russia & 18 & Luxembourg & 34 \\
\hline Cyprus & 18 & USA & 33 \\
\hline Iceland & 17 & Macedonia & 31 \\
\hline Slovakia & 17 & Chile & 30 \\
\hline Macedonia & 16 & China & 30 \\
\hline Argentina & 16 & New Zealand & 30 \\
\hline Ireland & 16 & Cyprus & 29 \\
\hline South Korea & 14 & Ireland & 27 \\
\hline Chile & 13 & Brazil & 23 \\
\hline China & 11 & Russia & 23 \\
\hline Turkey & 10 & Argentina & 22 \\
\hline Brazil & 10 & Turkey & 18 \\
\hline India & 8 & India & 14 \\
\hline Egypt & 7 & Egypt & 13 \\
\hline South Africa & 7 & South Africa & 12 \\
\hline Nigeria & 6 & Nigeria & 7 \\
\hline Kenya & 5 & Kenya & 6 \\
\hline
\end{tabular}

* Note: 2005 data

Source: ONS, Eurostat, OECD, UN ${ }^{16}$

The projected OADR for the UK in 2035 is again similar to the average for the EU (40). Relatively large OADR increases are projected for Germany, Malta, the Netherlands, Finland, Poland, 
Slovenia and Slovakia over the next quarter century. By contrast, relatively low increases are projected for Ireland, Cyprus, Estonia and Latvia. Germany and Italy are expected to maintain the highest OADRs in the EU (53 and 48 respectively) by 2035, while Ireland is expected to remain the lowest (27).

Japan's OADR is projected to increase to 57 by 2035, making it by some distance the country with the highest projected ratio of older dependants to younger adults. Russia is projected one of the lowest OADRs in Europe by 2035 (23); the explanation for this may lie in the low life expectancies for that country (see Figure 6). Outside Europe, China is projected one of the largest increases in OADR over the next quarter century (from 11 to 30 ). In sub-Saharan African countries such as Nigeria, the OADR is projected to increase only very slightly (from 6 to 7 ); however, in northern African countries, such as Egypt, the OADR is projected to rise to 13 by 2035 .

In general, the OADR is lower in countries with less developed economies than in developed countries and is projected to remain relatively low. However, the proportional rises in the OADR for countries with emerging economies is projected to be higher than in developed countries, as these countries experience more rapid ageing. It is in the historically most developed countries of western Europe and Japan where the current high OADRs are likely to continue and be most accentuated; the underlying reasons for this are mainly high longevity and also sustained low fertility. The UK, with relatively high fertility levels typical of northern Europe, and relatively modest life expectation improvements by European standards, has lower projected OADRs than those projected for Germany, Italy and Japan.

In those countries where public pension arrangements exist, these differ considerably in terms of statutory retirement ages, required levels of contributions to receive a full pension and levels of pension incomes. However, regardless of these variations, for any country, government expenditure can be expected to increase in line with any increase in their OADR.

Partly in response to projected rises in OADR, many country's governments have already introduced, or are planning to introduce, measures to increase statutory retirement age and incentives to encourage people to stay in work for longer. For example, in the UK the state pension age (SPA) for women is gradually being increased from 2010 to equalise with that of men after which the SPA for both men and women will rise to 68 by $2046^{17}$. In France, the government is introducing measures to raise state retirement age from 60 to 62 and recent reform in Germany will increase state retirement age from 65 to 67 over the period 2012 to 2029.

\section{Migration}

Table 4 summarises the estimated numbers of the 40 most common non-UK nationalities living in the UK in 2009. With over half a million citizens in the UK, Poland is at the top of the table. This is over one and a half times the number of citizens from the next largest source, Ireland. Of particular interest are countries currently experiencing political unrest; for example, Zimbabwe and Somalia are both towards the top of the table, with 76 and 59 thousand citizens in the UK respectively. At $32 \mathrm{nd}$ in the table, Iran is the top of the Middle Eastern nations. The majority of nations are similarly positioned as in the equivalent 2008 table, suggesting that these estimates are slow to respond to external circumstances. 


\section{Table $4 \quad$ Estimated population resident in the UK by foreign nationality, 2009}

40 most common nationalities

\begin{tabular}{|c|c|c|c|c|c|c|c|}
\hline \multicolumn{4}{|c|}{ 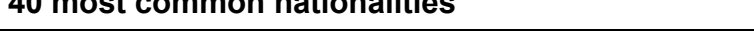 } & & & \multicolumn{2}{|c|}{ thousands } \\
\hline & Nationality & Estimate & $\mathrm{Cl}+$-** $^{*}$ & & & Estimate & $\mathrm{Cl}+$-* $^{*}$ \\
\hline 1 & Poland & 529 & 31 & 21 & Romania & 53 & 10 \\
\hline 2 & Republic of Ireland & 333 & 24 & 22 & Slovakia & 52 & 10 \\
\hline 3 & India & 303 & 23 & 23 & Ghana & 49 & 9 \\
\hline 4 & Pakistan & 190 & 18 & 24 & Jamaica & 47 & 9 \\
\hline 5 & United States of America & 139 & 16 & 25 & Turkey & 46 & 9 \\
\hline 6 & France & 125 & 15 & 26 & Brazil & 46 & 9 \\
\hline 7 & Germany & 113 & 14 & 27 & Netherlands & 45 & 9 \\
\hline 8 & Italy & 101 & 14 & 28 & New Zealand & 42 & 9 \\
\hline 9 & South Africa & 99 & 13 & 29 & Nepal & 41 & 9 \\
\hline 10 & Nigeria & 98 & 13 & 30 & Malaysia & 39 & 8 \\
\hline 11 & Portugal & 95 & 13 & 31 & British Indian Ocean Territory & 38 & 8 \\
\hline 12 & China & 88 & 13 & 32 & Iran & 36 & 8 \\
\hline 13 & Australia & 80 & 12 & 33 & Bulgaria & 34 & 8 \\
\hline 14 & Philippines & 79 & 12 & 34 & Sri Lanka & 34 & 8 \\
\hline 15 & Bangladesh & 77 & 12 & 35 & Greece & 31 & 7 \\
\hline 16 & Zimbabwe & 76 & 12 & 36 & Iraq & 31 & 7 \\
\hline 17 & Lithuania & 76 & 12 & 37 & Afghanistan & 29 & 7 \\
\hline 18 & Spain & 63 & 11 & 38 & Japan & 29 & 7 \\
\hline 19 & Somalia & 59 & 10 & 39 & Sweden & 28 & 7 \\
\hline 20 & Canada & 56 & 10 & 40 & Czech Republic & 28 & 7 \\
\hline
\end{tabular}

Source: Annual Population Survey and Labour Force Survey, ONS

Note: *As data are calculated from a sample survey the 'Estimate' is not an exact count of foreign citizens. The confidence interval shows it is $95 \%$ certain that the true value of the estimate is within the interval of the estimate, plus or minus the number in the $\mathrm{Cl}+/-$ column.

\section{Table $5 \quad$ Estimated number of UK citizens emigrating to the top 10 destination countries, 2005-2009 combined}

\begin{tabular}{rrrr}
\hline & $\begin{array}{r}\text { Country of next } \\
\text { residence }\end{array}$ & $\begin{array}{r}\text { Thousands } \\
\text { emigrating }\end{array}$ & $\mathbf{C l}+/-$ \\
\hline 1 & Australia & 195 & 15 \\
2 & Spain & 102 & 22 \\
3 & France & 76 & 21 \\
4 & USA & 62 & 10 \\
5 & New Zealand & 56 & 8 \\
6 & Canada & 33 & 6 \\
7 & Germany & 32 & $15^{\dagger}$ \\
8 & United Arab Emirates & 23 & 5 \\
9 & Netherlands & 16 & $10^{\dagger}$ \\
10 & Thailand & 13 & 4 \\
\hline
\end{tabular}

Source: International Passenger Survey, ONS

Note: *As data are calculated from a sample survey the 'Estimate' is not an exact count of foreign citizens. The confidence interval shows it is $95 \%$ certain that the true value of the estimate is within the interval of the estimate, plus or minus the number in the $\mathrm{Cl}+/$ - column.

${ }^{\dagger}$ Confidence Intervals are wide indicating that these estimates are not robust 
Table 5 summarises the top ten destination countries for emigrating UK citizens in the period 2005-2009; four out of these ten are English-speaking, while Spain and France have long been popular destinations for retired UK citizens.

Figure 10 contains OECD migration data showing the percentage of resident foreign born population in a selection of countries. The UK level of just over 10 per cent in 2007 is in the midrange for western European nations. Compared with non-European developed countries, the UK's proportion of foreign born population is below that of the USA, Canada, Australia and New Zealand.

Around one in ten of the UK's resident population were foreign born in 2007; this was in the mid-range for western European nations and lower than that of the USA, Canada, Australia and New Zealand

\section{Figure 10 Stocks of foreign-born as a percentage of the population, in selected countries, 2007 where not stated}

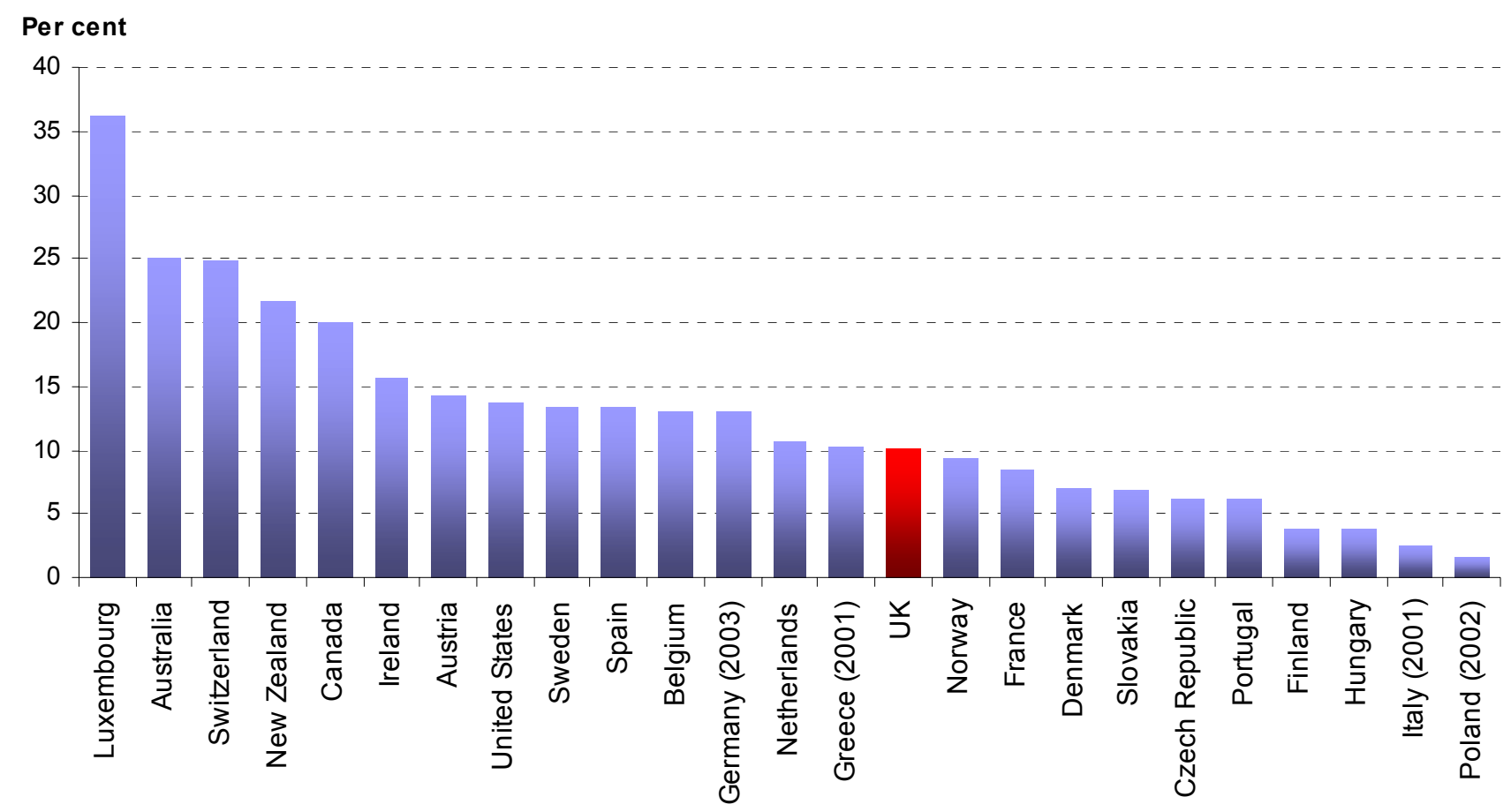

Source: OECD online, Table A.1.4. Stocks of foreign-born population in selected OECD countries

A similar pattern can be observed comparing flows of migrants per thousand of the resident population. Figure 11 shows net migration to the countries shown per thousand population. Net migration is the difference between immigration and emigration and therefore can mask the size of these individual gross flows. The UK is ranked in the middle of the European countries, and falls 14th out of the 25 in this international sample; however, unlike the stocks data, the non-European 
developed nations are more scattered, with both the USA and New Zealand at a lower level than the UK.

\section{Figure $11 \quad$ Net migration in selected countries, 2007 where not stated}

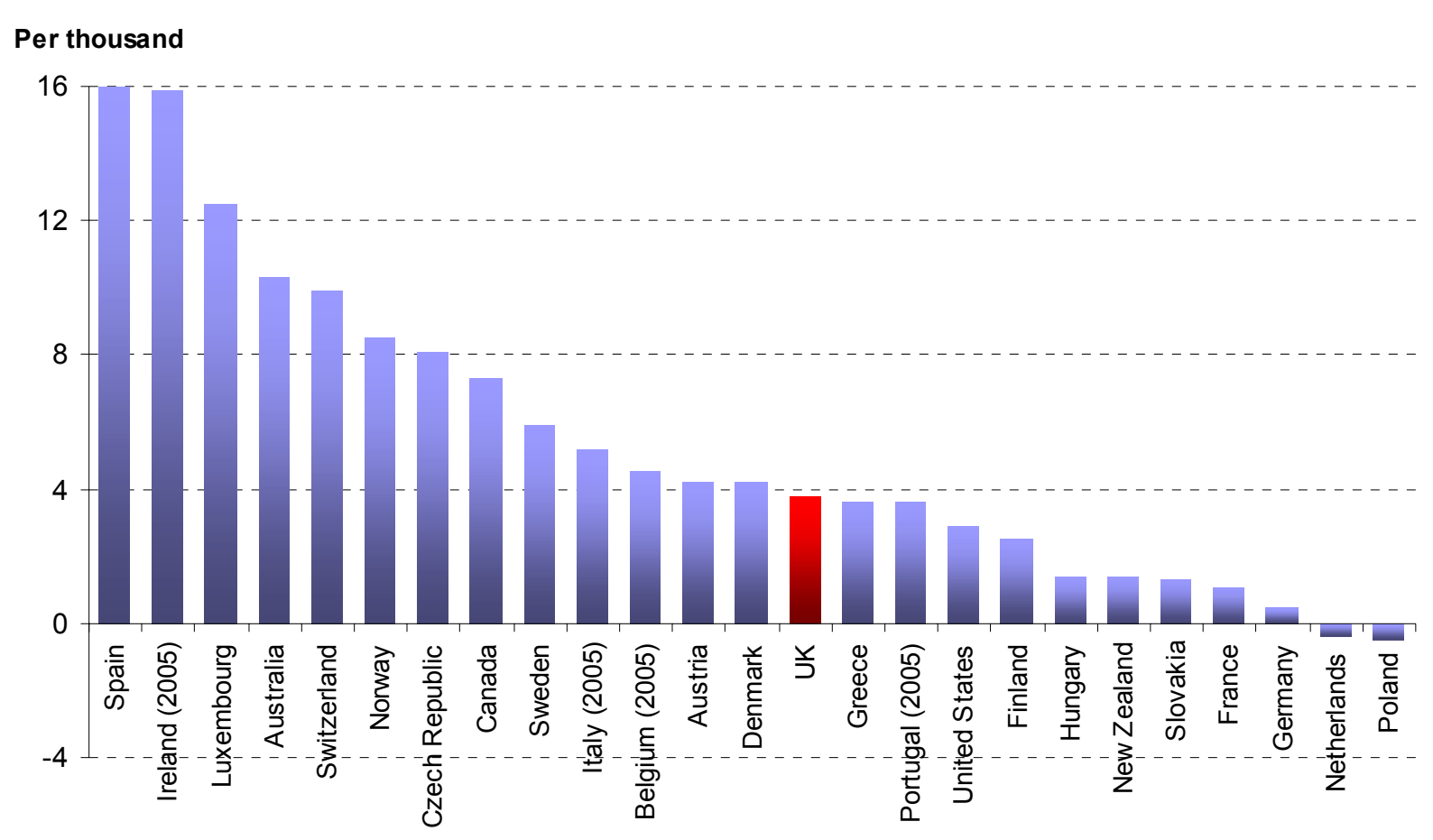

Source: OECD Factbook 2010, UK Data calculated from ONS figures

\section{Population Density}

The estimated 61.8 million people usually resident in the UK in mid-2009 equates to 255 people per square kilometre of land area ${ }^{18}$. However, the population is not evenly distributed throughout the UK, and patterns of population density at country and regional levels illustrate this.

\section{Table 6 Estimated resident population density mid-1981 to mid- 2009}

\begin{tabular}{lrrrrr}
\hline & Land Area & \multicolumn{4}{c}{ People per Sq. km } \\
Country & (Sq Km) & $\mathbf{1 9 8 1}$ & $\mathbf{1 9 9 1}$ & $\mathbf{2 0 0 1}$ & $\mathbf{2 0 0 9}$ \\
\hline United Kingdom & 242,000 & 230 & 237 & 244 & 255 \\
& & & & & \\
England & 130,000 & 359 & 367 & 380 & 398 \\
Wales & 21,000 & 136 & 139 & 140 & 145 \\
Scotland & 78,000 & 66 & 65 & 65 & 67 \\
Northern Ireland & 14,000 & 114 & 118 & 124 & 132 \\
\hline
\end{tabular}

Source: Office for National Statistics

The population density of the UK has increased since 1981. Table 6 shows the population density in 1981, 1991, 2001 and 2009 in each of the UK constituent countries. England has consistently had the highest population density of the UK constituent countries, reaching 398 people per square 
kilometre in mid-2009. Scotland has the lowest population density, with 67 people per square kilometre, virtually unchanged since 1981.

London is by far the most densely populated region of England, with 4,932 people per square kilometre in mid-2009 (see Table 7). The eight other regions of England all had population densities of between 219 (South West) and 489 (North West) people per square kilometre.

\section{Table 7 Estimated resident population density by GOR, mid-1981 to mid-2009}

\begin{tabular}{lrrrrr}
\hline & Land Area & \multicolumn{4}{c}{ People per Sq.km } \\
Government Office Region & (Sq Km) & $\mathbf{1 9 8 1}$ & $\mathbf{1 9 9 1}$ & $\mathbf{2 0 0 1}$ & $\mathbf{2 0 0 9}$ \\
\hline North East & 9,000 & 307 & 302 & 296 & 301 \\
North West & 14,000 & 492 & 485 & 480 & 489 \\
Yorkshire and The Humber & 15,000 & 319 & 320 & 323 & 341 \\
East Midlands & 16,000 & 247 & 257 & 268 & 285 \\
West Midlands & 13,000 & 399 & 402 & 406 & 418 \\
East & 19,000 & 254 & 268 & 283 & 302 \\
London & 2,000 & 4,329 & 4,344 & 4,658 & 4,932 \\
South East & 19,000 & 380 & 400 & 421 & 442 \\
South West & 24,000 & 184 & 197 & 207 & 219 \\
\hline
\end{tabular}

Source: Office for National Statistics

A key feature of the UK's population is the significant variation in population density across the constituent countries and regions: Scotland has one of the lower population densities of any EU country, while the North West and South East regions of England have densities far higher than nearly all EU countries.

Overall population density of the UK is high in comparison to the 48 people per square kilometre across the world as a whole ${ }^{19}$. The UK has the fourth highest population density of the 27 countries of the European Union, after Malta (1281), the Netherlands (485) and Belgium (350). Finland has the lowest population density in the EU with only 17 people per square kilometre. Germany has a similar population density to the UK, with 230 people per square kilometre ${ }^{20}$.

The UK is the fourth most densely populated EU nation after Malta, the Netherlands and Belgium

Worldwide, the UK's average population density of 255 per square kilometre is matched by a disparate range of countries, including Jamaica (245), Vietnam (257) and El Salvador (291) ${ }^{21}$. In contrast, Australia, Iceland, Canada and Russia have fewer than ten people per square kilometre (3 for Australia ${ }^{22}$ and Iceland, 4 for Canada ${ }^{23}$ and 8 for Russia). Argentina (14), Brazil (22), Chile (22), New Zealand (16), the USA (32), South Africa (40), Kenya (66) and Egypt (75) all have low population densities. It should be noted that countries such as Australia and Egypt have deceptively low population densities owing to large tracts of relatively uninhabited territory including 
desert regions. Sri Lanka (308), Japan (338), India (350) and South Korea (487) each have high population densities.

Map 1 identifies the countries compared above and illustrates their comparative population densities.

\section{Map 1 Population density for world countries, $2009^{1}$}

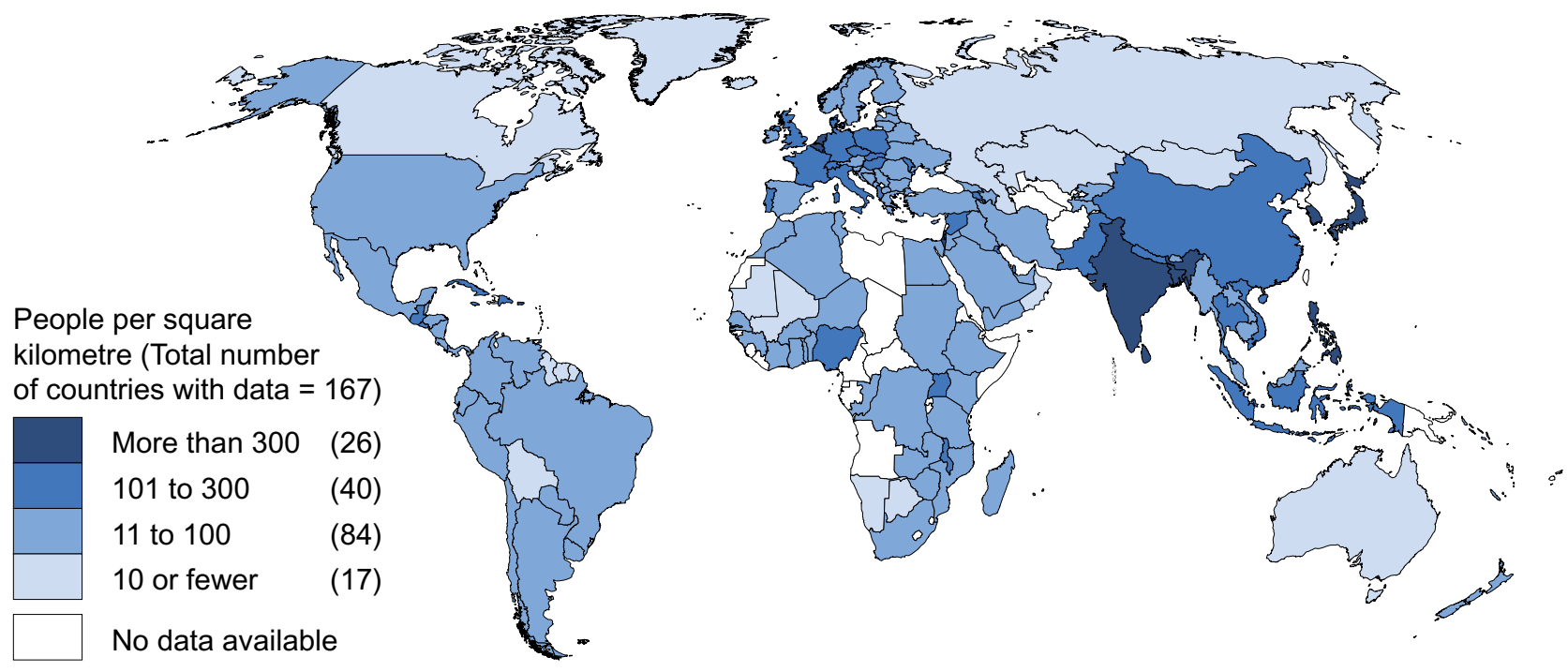

1 Population density figures are the latest available at the time of writing and range from 2006 to 2009.

Source: Office for National Statistics; UN Demographic Yearbook; Eurostat; Australian Bureau of Statistics; World Bank (c) Crown copyright. All rights reserved ONS100019153. 2010.

\section{Conclusion}

This comparative demographic overview shows that the UK has:

- fertility in line with the quite high levels of much of northern Europe (France, Ireland, Belgium, the Netherlands and the Scandinavian countries) and similar to those of Australia and New Zealand;

- improved and improving life expectation at birth, in line with most western European countries;

- an ageing population, but not as aged as the levels predicted for Germany, Italy and Japan;

- a population with around one in ten residents foreign-born, a lower proportion than nonEuropean developed countries such as the USA, Canada, Australia and New Zealand;

- one of the highest population densities in Europe, with especially high levels found in England.

Effective comparisons of demographic patterns within and between countries depend on accurate data collection. Numbers of births and deaths are measured in many countries using compulsory vital registration of these events. More difficult is the accurate and detailed measurement of migration, both international and intra-national, and the methods used to achieve this vary considerably by country. What binds all of these three demographic components together, along with measures of ageing, and permits the derivation of measures of population density, is an effective and up-to-date enumeration of the numbers of people living within a country, at different levels of geography. It is the accurate measurement of the population that will determine the 
reliability of many statistics where population estimates are used as the denominator. The forthcoming March 2011 censuses within the UK, covering England and Wales, Scotland and Northern Ireland, should permit the necessary benchmarking to achieve these ends over the next decade. Beyond the 2011 Census, ONS is currently investigating how best to measure populations in an increasingly complex and mobile society, a challenge shared by many statistical agencies throughout the world.

\section{Acknowledgements}

The author is grateful to topic experts in the ONS Centre for Demography for their input to this article; the material was collated by Chris W Smith and Ben Winkley within the Population Trends editorial team, and typeset by Alan Aplin. The author gratefully acknowledges the constructive comments on earlier drafts made by colleagues from ONS, GROS, NISRA, WAG and other government departments.

\section{References}

1 The European Union consists of the following 27 countries: Austria, Belgium, Bulgaria, Cyprus, Czech Republic, Denmark, Estonia, Finland, France, Germany, Greece, Hungary, Ireland, Italy, Latvia, Lithuania, Luxembourg, Malta, The Netherlands, Poland, Portugal, Romania, Slovakia, Slovenia, Spain, Sweden and the UK.

Note: Bulgaria and Romania joined in 2007 and are sometimes excluded from data for historical comparisons.

2 Office for National Statistics (2009) Information on latest UK Population Estimates available at: www.statistics.gov.uk/CCl/nugget.asp?ID=6

3 Office for National Statistics (2009) Information on latest UK national population projections available at: $\underline{w w w . s t a t i s t i c s . g o v . u k / s t a t b a s e / P r o d u c t . a s p ? v l n k=8519}$

4 The total fertility rate (TFR) is the number of live children a group of women would have if they experienced the age-specific fertility rates for the calendar year in question throughout their childbearing lifespan.

5 Period and Cohort Life Expectancy - explains two different measures of mortality rates www.statistics.gov.uk/cci/nugget.asp?id=1898

6 OECD data bank [www.oecd.org/dataoecd/50/62/42294003.xls]

2005: Australia and Canada

2006: Iceland, Japan, New Zealand and the USA

2007: Belgium and Italy

Data for the UK are for 2008 and are taken from Table 2.1 of Population Trends [see:

www.statistics.gov.uk/downloads/theme health/Vital-stats-summary21.xls] 
Data for Brazil, China, Chile, India, Kenya, Mexico, Nigeria, and South Africa are from the World Bank Indicators, 2008.

Data for Egypt is for 2008, from CAPMAS

Data are from Eurostat for 2008 for all other countries.

7 The percentage of births outside marriage is the number of live births that took place outside marriage as a proportion of the total number of live births. See:

http://epp.eurostat.ec.europa.eu/cache/ITY SDDS/EN/demo fer esms.htm

OECD data bank [www.oecd.org/dataoecd/50/62/42294003.xls]

2005: Australia and Canada

2006: Iceland, Japan, New Zealand and the USA

2007: Belgium and Italy

Data for the UK are for 2008 and are taken from Table 2.1 of Population Trends [see:

www.statistics.gov.uk/downloads/theme health/Vital-stats-summary21.xls]

Data are from Eurostat for 2008 for all other countries.

9 ONS Interim Life Tables, 2007-09 and UN life expectancy estimates, 2008 revision.

ONS life expectancy figures are based on three years aggregated population and deaths data whereas UN figures are based on five years aggregated deaths data.

10 Office for National Statistics (2009). Information on ageing of the UK population. Available at: www.statistics.gov.uk/cci/nugget.asp?ID $=949$

11 Eurostat: estimates for Germany include ex-GDR.

12 Eurostat: projected estimates for 2035 for European Union countries and for Norway and Switzerland; United Nations projected estimates for 2035 for other countries.

13 Population projections for UK 2035 are ONS National Population Projections (NPP) 2008 based.

14 UK 2009 Mid-year population estimates, 2035 NPP 2008-based

EU27: Eurostat 2009 population estimates and 2008 based 2035 projections

Other countries: OECD 2008 population estimates (except Kenya and Nigeria which are UN 2005 estimates) and UN 2035 projections (based on most recent population data available for each country)

15 Sources for the estimated and projected OADR:

European countries - Eurostat 2008 database for estimated population and 2035 projected population; for the UK 2008 ONS Mid-year population estimates and 2035 National Population Projections 2008-based

Other countries: OECD for 2008 estimated population and UN for 2035 population projections.

It should be noted that in this article use is made of the international standard of age 15-64 to calculate OADRs, rather than age 16 to state pension age, which is more commonly used in the UK. 
UK: OADR estimates based on ONS Mid-year population estimates, 2008

EU27: OADR are Eurostat estimates for 2008

Other countries: OADR estimates based on OECD 2008 data except for Argentina, Egypt, Kenya, Nigeria which are UN 2005 estimates

2035 table:

UK: 2035 OADR projected based on ONS NPP 2008-based projections

EU27: 2035 OADR projected (based on 2008 based projections) Eurostat

Other countries: 2035 OADR projected (based on most recent UN population data available for each country)

17 Under current legislation State Pension Age (SPA) for men and women will be equalised at age 65 by 2020 . However, the Government has decided that the increase in SPA to 66 should be brought forward to 2020. The Government will introduce a Bill in 2011 to implement this change. If Parliament approves the Government's proposals, the SPA for both men and women will rise from 65 in December 2018 to 66 by April 2020. To enable this earlier increase to 66, the equalisation timetable will be adjusted from April 2016 so that women's SPA will reach 65 by November 2018. The government is also considering the current timetable for future increases to the SPA from 66 to 68 . Any change to the timetable would require the approval of Parliament.

18 UK population density used throughout this section is the number of people per square kilometre of land area. Land area measurements are based on 2007 information.

19 Definitions of population density vary between countries, and individual definitions are provided; however, the data are considered to be broadly comparable.

Common source for population density and definitions: UN Statistical Yearbook 2009 http://unstats.un.org/unsd/syb/syb52.pdf

20 Population density figures for the 26 member countries of the European Union (ONS figures are used for UK) are the latest available published on the Eurostat website. See:

http://epp.eurostat.ec.europa.eu/tgm/table.do?tab=table\&init=1\&language=en \&pcode=tps000 $\underline{03 \& \text { plugin }=1}$

21 UN Demographic Yearbook Table 3, http://unstats.un.org/unsd/demographic/products/dyb/dyb2008/Table03.xls

22 Australian Bureau of Statistics. www.abs.gov.au/ausstats/abs@.nsf/Products/3218.0 200809 Main+Features Main+Features?OpenDocument\#PARALINK1

23 Statistics Canada 